\title{
Isolation and Activity of Amylase Enzyme in Isolates of Fungi From Black Rice Lemang (Oryza sativa Siarang)
}

\author{
Mades Fifendy ${ }^{1 *}$ Periadnadi ${ }^{2}$ Gustina Indriati ${ }^{3}$ Syovia Osnita ${ }^{3}$ Lara Annisa ${ }^{3}$
}

\author{
${ }^{1}$ Dept. of Biology, Faculty of Mathematics and Science (FMIPA), Universitas Negeri Padang, Padang, Indonesia \\ ${ }^{2}$ Dept. of Biology, Faculty of Mathematics and Science (FMIPA), Andalas University, Padang, Indonesia \\ ${ }^{3}$ Biology Program StudySTKIP PGRI SumbarPadang, Indonesia \\ *Corresponding author. Email: madesfifendy@yahoo.co.id
}

\begin{abstract}
Black rice Lemang (Oryza sativa Siarang) from Kenagarian Talang Babungo is one of the Minangkabau specialties. Lemang left moldy to get a different taste from ordinary lemang. This fungus occurs in chemical processes that are assisted by the amylase enzyme that functions to break down starch into simple sugar units. The purpose of this research was to find the type of fungus found in black rice lemang and to find out the activity of the fungus amylase enzyme which was isolated from black rice lemang. The study was conducted at the Microbiology Laboratory of Andalas University, Padang from March to April 2016. This study used a descriptive survey method by isolating fungi, making pure seedlings, and then identifying and descriptive methods by growing fungi isolates on rice flour medium (ATB) to identify the amylase fungal enzymes that were characterized. by the formation of open areas around the fungal colonies. The results of isolation and identification found five varieties of mold in lemang, namely Aspergillus niger, Aspergillus ustus, Aspergillus sp, Mucor racemosus, and Penicillium expansum. The highest amylolytic index is Penicillium expansum (1.5) and the lowest amylolytic index is Mucor racemosus (0.5).
\end{abstract}

Keywords: Black rice, Isolation, Identification, Descriptive Survey, Amylolytic Mushroom, Amylolytic Index

\section{INTRODUCTION}

In various places in West Sumatra Lemang is one of the special foods made during certain celebrations and specifically during Ramadan and Eid. The basic ingredients in making lemang are basically sticky rice, both black and white sticky rice. In the Solok Regency, most of the talang is Talang Babungo, lemang is made using black rice and candied sugar cane. The tradition of making lemang in the gutter of Talang Babungo made from black rice has been done for a long time. Lemang made by the Talang Babungo community is a unique and unique lemang, in addition to the basic ingredients used, the manufacturing process and the results of the lemang itself.

This lemang can also be consumed for more than 2-3 weeks, while this lemang has been overgrown with mold, but can still be consumed by heating or steaming again. Most people intentionally use this lemang with mold in order to obtain a different taste. Lemang that has been floating will have a slightly sour taste because it is caused by mold growing on the lemang.

Fungi are microbes that cannot meet the nutritional requirements of autotrophs, so they live on saprophytes or parasites in other creatures. Mold can grow on various substrates, especially those containing carbohydrates and can live in acidic conditions[1]. In addition to food, mold is also widely available in the air, that air is the most important component to maintain life because bodily relations are not possible without oxygen in the air[2]. Contaminated natural food has increased the quality, good taste, nutrition, texture, and produce toxins that cause these foods to be dangerous for consumption.

The fungi grown by this fungus not only change taste, but also occur various chemical reactions that cause changes related to cellular processes by organic compounds produced by the fungal cells themselves such as the amylase enzyme. This amylase enzyme can catalyze the hydrolysis reaction of the polysaccharide chain into simpler units, such as breaking down starch into smaller sugar units and also being able to hydrolyze flour into maltose. Enzymes produced by microorganisms, both fungi can produce sugar from starch.

In natural fermentation media such as food from these lemang there are substrates that can be broken down by amylase-producing microorganisms. Black rice which is used as a basic ingredient for making this lemang contains starch which is one of the natural media for the amylolytic process. Thus, there is a strong suspicion that amylolytic microorganisms grow naturally and develop in the lemang. Microorganisms such as bacteria and mold can produce various kinds of enzymes, including the amylase enzyme. Amylase enzyme is one of the enzymes that is able to catalyze the hydrolysis of bond $(\alpha 1,4)$ glycosides in carbohydrate polymer compounds with the general formula $(\mathrm{C} 6 \mathrm{H} 16 \mathrm{O} 5) \mathrm{n}$. The amylase enzyme can be used to convert starchy materials into simpler monomers in the form of glucose, dextrose, fructose or maltose. The use of 
amylase enzymes is very large in the food, pharmaceutical and textile industries[3].

Amylase enzymes can be grouped into, namely: 1) $\alpha$ amylase, which breaks starch randomly from the middle or from the inside of the molecule, 2) $\beta$-amylase, which can hydrolyze sugar units from the end of the starch molecule, and 3) Glukoamilase, which can separate glucose from the terminal non-reducing starch substrate [4].

Amylase enzyme is an enzyme that can be produced by fungi. Fungi that produce amylase are usually called amylolytic fungi. From several studies, the fungus that is able to produce amylase enzymes comes from the genus Penicillium, Mucor, Neurospora, Aspergilus, Rhizopus, and Chepalosporium.

Amylase enzymes produced by Rhizopus in aerobic conditions produce many extracellular amylase enzymes[5]. The enzyme is produced to break down complex compounds into simpler compounds, so that they can be absorbed by cells and can be used for growth.

\section{MATERIALS AND METHODS}

The research method is a descriptive survey method that is doing direct observation using fungi contaminated with fungi. Then grow the fungus on the media and identify the types of mold contained in the media derived from black rice glue and descriptive method, which is to grow the fungus on the ATB media and measure the diameter of the clear zone formed and divided by the diameter of the growing fungus colony.

The tools used in this study were knives, tissue, cloth, plastic, scissors, petri dishes, tweezers, $15 \mathrm{~mL}$ measuring cups, autoklav, test tubes, test tube racks, erlenmeyer, label paper, rubber bands, A4 paper, Bunsen, glass beaker, gas stove, spoon, stirring rod, analytical balance (OHaus), inoculum needle, vortex, micro pipette, refrigerator, aluminum voil, paper wrap, sanitary napkin, lighters, matched pipette, filler and camera.

The materials needed in this study are black rice, PDA medium, $70 \%$ alcohol, sterile distilled water, spiritus, yeast extract, rice flour, Chloramfenicol, and agar agar, cotton, tissue, black rice lemur, instant PDA, 70\% alcohol, sterile aquades, spritus, Chloramfenicol.

\subsection{Planting samples on PDA media}

Planting samples using the Pour Plate method (agar pour). This technique requires that those that are not yet solid (> $45^{\circ} \mathrm{C}$ ) be poured together with suspensions (lemons and sterile aquades) into a petri dish then homogenized and allowed to solidify. In planting this sample using a dilution with the pour plate method at a dilution rate of $10^{-1}-10^{-12}$. Samples were taken using a knife that has been sprayed with $70 \%$ alcohol by bringing a part that is covered with mushrooms as much as 1 gram. The part is pounded using mortar until smooth. The crushed lime is then put into a tube that is not labeled to be homogenized, after that take 1 $\mathrm{ml}$ of the suspension and move the savings to $10^{-1}$, then homogenize using vortex. After that the solution is taken as much as $1 \mathrm{ml}$ and put into savings $10^{-2}$ and homogenized again. Each suspension in the tube is homogenized again and taken as much as $1 \mathrm{ml}$ then put into a labeled petri dish. Pour the liquid media $\left(>45^{\circ} \mathrm{C}\right)$ into a petri then turn the cup to homogenize the suspension and the media, then incubate for 1-3 days.

\subsection{Fungi Identification}

Macroscopic observation

Observe the morphology of the colony, namely the color of the colony, the shape of the colony, and the surface of the colony using the reference book[6][7].

b. Microscopic observation

Done by taking a fungus colony that grows on the media using an ose needle and placed on the slide, then dripping with $70 \%$ alcohol. Then cover with a glass cover and observe under a microscope with a magnification of $10 \mathrm{x}$ 10 or $10 \times 40$ so that it can be seen hyphae and other parts (mycelium color, spore head, khlamidospora, sporangiofor, stolon, rhizoid, and so on).

c. Mushroom identification

The fungus obtained from observations using a microscope was then photographed, and identified using the[6].

d. Testing fungal amylolytic activity

The identified fungus was inoculated on the rice flour agar medium (ATB) and incubated at room temperature for 1-3 days. Clear zones formed around the colony indicate that the fungus has amylolytic activity.

Measurement of amylolytic mushroom index

Amylolytic index measurements are calculated based on the quotient of the diameter of the clear zone to the diameter of the colony [8].

Amylolytic Index $=\frac{\text { (average clear zone diameter) }- \text { (average colony diameter) }}{\text { average colony diameter }}$

\section{RESULT AND DISCUSSION}

The results of isolation and identification of molds found in black rice lemang (Oryza sativa Siarang) obtained 5 types of molds, namely Aspegillus niger, Aspergillus ustus, Aspergillus sp., Mucor racemosus, and Penicillium expansum. 
Table 1. Results of identification of types of molds found in Black Rice Lemang (Oryza sativa Siarang)

\begin{tabular}{|c|c|c|}
\hline 1. Asp & $\begin{array}{l}\text { Colonies } \\
\text { (Macroscopic) }\end{array}$ & $\begin{array}{l}\text { Microscopic } \\
\text { observation }\end{array}$ \\
\hline & $\begin{array}{l}\text { Young colonies are } \\
\text { white, colonies are } \\
\text { formed on the } \\
\text { surface of the media, } \\
\text { the surface of the } \\
\text { colony looks } \\
\text { compact, the growth } \\
\text { also shows the } \\
\text { appearance of } \\
\text { hyphae }\end{array}$ & $\begin{array}{l}\text { hyphae insulated, } \\
\text { conidia head black, } \\
\text { round, smooth-walled. } \\
\text { Fialid sits on a } \\
\text { metulae, conidia are } \\
\text { round to semi round, } \\
\text { dark brown-black, and } \\
\text { ornamental }\end{array}$ \\
\hline 2. $A s$ & $\begin{array}{l}\text { Colonies } \\
\text { (Macroscopic) }\end{array}$ & $\begin{array}{l}\text { Microscopic } \\
\text { observation }\end{array}$ \\
\hline & $\begin{array}{l}\text { Colonies when } \\
\text { young are white, in } \\
\text { the form filaments } \\
\text { and will turn to after } \\
\text { forming conidia. } \\
\text { Colonies grow on } \\
\text { the surface of the } \\
\text { media. surface of the } \\
\text { colony granular. }\end{array}$ & $\begin{array}{l}\text { hyphae have septa, } \\
\text { conidiophores erect, } \\
\text { conidiophores bulge to } \\
\text { form vesicles and } \\
\text { there are sterigmata, at } \\
\text { the ends of the sterig- } \\
\text { eye attach to conidia } \\
\text { which are arranged to } \\
\text { form conidial chains. }\end{array}$ \\
\hline & $\begin{array}{l}\text { Colonies } \\
\text { (Macroscopic) }\end{array}$ & $\begin{array}{l}\text { Microscopic } \\
\text { observation }\end{array}$ \\
\hline & $\begin{array}{l}\text { Young yellow } \\
\text { colony with a } \\
\text { granular surface, the } \\
\text { blackish brown, of } \\
\text { the colony turns } \\
\text { black and there are } \\
\text { filaments. Colonies } \\
\text { spread on the } \\
\text { surface of the media. }\end{array}$ & $\begin{array}{l}\text { The head of the } \\
\text { conidia is brownish in } \\
\text { color, has a bulkhead, } \\
\text { the phialid appears on } \\
\text { the vesicles, the } \\
\text { conidia are scattered, } \\
\text { ornate and brownish } \\
\text { yellow }\end{array}$ \\
\hline $\begin{array}{ll}4 . & \text { Mucor } \\
\text { racemosus } & \\
\end{array}$ & $\begin{array}{l}\text { Colonies } \\
\text { (Macroscopic) }\end{array}$ & $\begin{array}{l}\text { copic } \\
\text { ation }\end{array}$ \\
\hline & $\begin{array}{l}\text { Young colonies are } \\
\text { white, then turn } \\
\text { brownish gray after } \\
\text { forming } \\
\text { conidiospores. Its } \\
\text { growth is very fast. } \\
\text { Colonies grow on } \\
\text { the surface of the } \\
\text { media and look like } \\
\text { cotton. }\end{array}$ & $\begin{array}{l}\text { Hifa is not insulated, } \\
\text { has short curved } \\
\text { branches. Sporanganya } \\
\text { brownish, rounded } \\
\text { column and no stolons. }\end{array}$ \\
\hline $\begin{array}{l}5 . \quad \text { Penicillium } \\
\text { expansum }\end{array}$ & $\begin{array}{l}\text { Colonies } \\
\text { (Macroscopic) }\end{array}$ & $\begin{array}{l}\text { Microscopic } \\
\text { observation }\end{array}$ \\
\hline & $\begin{array}{l}\text { The young colony is } \\
\text { bluish green, around } \\
\text { the colony there is a } \\
\text { radial line (which is } \\
\text { one of the } \\
\text { characteristics of the } \\
\text { Penicillium mold). } \\
\text { The surface of the } \\
\text { colony looks like } \\
\text { velvet. }\end{array}$ & $\begin{array}{l}\text { Hyphae are insulated, } \\
\text { conidiophores of } \\
\text { quarter verticillate } \\
\text { type, at the ends of the } \\
\text { conidiophores there } \\
\text { are fialids that join the } \\
\text { metulae, and conidia } \\
\text { are ovoid shaped and } \\
\text { radially arranged. }\end{array}$ \\
\hline
\end{tabular}

The results of identification of mold isolates found in black rice lemang, obtained 5 types of mold, namely Aspergillus niger, Aspergillus ustus, Aspergillus sp., Mucor racemosus, and Penicillium expansum. The time needed for the emergence of mold colonies ranges from 310 days. The fastest growing mold is the Mucor type, while the one that needs the longest time to grow is the Penicillium type. As that the growth of mold colonies including the genus Penicillium is slow, the colony diameter can reach $52 \mathrm{~mm}$ after 10 days of incubation [6]. Mold suspected as an airborne contaminant in black rice lemang is a type of mold Aspergillus and Penicillium. Both types of mold are found in many spores, especially Aspergillus niger. Which states that both types of mold can be easily isolated through the air [2]. That Aspergillus niger is a cosmopolite in the tropics and subtropics, easily isolated from air, soil, water, spices, cotton, fruits, wheat, rice, corn, sugar cane, coffee, tea and leaf litter [9]. These molds also produce citric acid which is thought to be the cause of the acid taste in the fungi growing with mold.

Aspergillus ustus isolate is a type of mold that is generally found in food. However, in some studies this type of mold was also found in waters as an indication of the presence of household waste in these waters [10]. The discovery of this type of mold in black rice lemang is thought to originate from black rice, water or candied sugar cane which was used during the process of making the black rice lemur dough.

Black rice which is used as a basic ingredient for making lemang contains high carbohydrates and minerals. These two elements are generally needed by molds for growth, especially Mucor molds. Mucor is found in the remnants of foods that contain lots of carbohydrates [11]. The type of Mucor found is a type that is commonly found in many foods, namely Mucor racemosus. This type of mold is very easy to breed on starch substrates. These molds can also be easily isolated in soil, bananas, sugar, rice, corn, some types of vegetables, and potatoes [6].

Other molds Penicillium is a fungus that is commonly grown in food products, especially processed products and fruits. States that Penicillium is very common in various food products such as fruits, spices, and low water content of food [12]. Penicillium expansum types are generally found in food and fruits, especially apples. Therefore, this type of mold is often used in research as an indicator for post-harvest disease control tests in fruit [13]. In general, mold contamination in lemang is suspected to occur due to the long storage process of lemang. Mold growth is also aided by minimal water content in the black rice lemang, according to the opinion [14] which states that mold requires minimal water for growth compared to yeast and bacteria. Supported by environmental conditions such as optimal water content and temperature allows microbes to make contact with food. States that water content can be reduced to a minimum so that microorganisms cannot grow again in it [15]. In addition, by not storing lemang too long. Because the longer it is stored it will be increasingly contaminated by undesirable microbes. Furthermore, by taking into account the process of making and storing the foliage before consumption in order to 
avoid contamination through the air or the materials used. As stated that microbes are spoiled for food if stored without rules [16].

Amylolytic mushrooms that have been successfully isolated from black rice lemang (Oryza sativa Siarang) obtained as many as 5 isolates.

The mushroom isolates obtained, are listed in Figure 1.

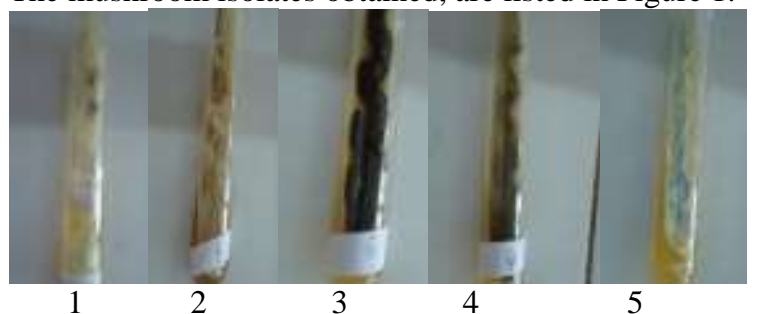

From the 5 isolates obtained as a whole showed that each amylolytic fungus has the ability to hydrolyze starch which is characterized by the formation of clear areas around the fungal colonies.

The clear regions formed are listed in Figure 2.

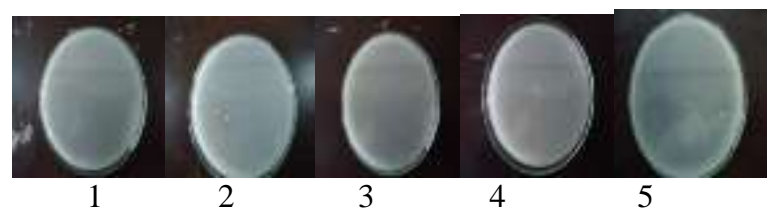

Figure 2. Clear areas formed by fungal isolates (marked with arrows). (1). Aspergillus niger, (2). Aspergillus ustus, (3). Mucor racemosus, (4). Aspergillus sp, (5). Penicillium expansum

Table 2. Measurement of fungal amylolytic index in isolates aged 2 days $(\mathrm{mm})$

\begin{tabular}{lllllllll}
\hline \multirow{2}{*}{ Isolate } & Colony & \multicolumn{2}{c}{ Diameter } & Aver & \multicolumn{2}{l}{ Colony } & Aver & Indx \\
& & 1 & 2 & age & 1 & 2 & age & \\
\hline & 1 & 4,5 & 13,5 & 9 & 2,5 & 5,5 & 4 & 1,25 \\
1 & 2 & 4,5 & 7,5 & 6 & 2,5 & 5 & 3,75 & 0,6 \\
\hline & 1 & 0 & 7 & 3,5 & 0 & 3 & 1,5 & 1,33 \\
2 & 2 & 0 & 6 & 3 & 0 & 3 & 1,5 & 1 \\
\hline & 1 & 6 & 11 & 8,5 & 5 & 6 & 5,5 & 0,55 \\
3 & 2 & 5 & 9 & 7 & 3 & 5 & 4 & 0,75 \\
\hline & 1 & 5,5 & - & 2,75 & 2,5 & - & 1,25 & 1,2 \\
4 & 2 & 4 & - & 2 & 2 & - & 1 & 1 \\
\hline & 1 & 6 & 12,5 & 9,25 & 4 & 7,5 & 5,75 & 0,61 \\
5 & 2 & 4 & 6 & 5 & 1 & 3 & 2 & 1,5 \\
\hline
\end{tabular}

Note: Isolate 1: Aspergillus niger Isolate 2: Aspergillus ustus Isolate 3: Mucor racemosus Isolate 4: Aspergillus sp Isolate 5: Penicillium expansum
The size of the diameter of the clear area formed from each isolate is different. This is due to the ability to hydrolyze the starch of each isolate is also different. Based on the data in table 1 , all 5 isolates were identified as having different amylolytic abilities. The highest amylolytic index is owned by the 5th isolate (Penicillium expansum) of 1.5. While the lowest amylolytic index was owned by the 3rd isolate (Mucor racemosus) of 0.55 . These results indicate that the 5th isolate was an amylase enzyme producer with high potential criteria, followed by the 2 nd isolate, the 4th isolate, and the first isolate with moderate potential criteria, and the 3rd isolate criterion had low potential.

The first isolate is the Aspergillus niger fungus with a characteristic seen in the picture of the Aspergillus niger colony is a part of the fine black conidiophores. Colonies are usually black grains caused by conidia that develop and grow as an asexual reproductive tool. According to that the fungus colony of Aspergillus niger on agar is white or bright yellow [17]. The next isolate, Aspergillus ustus, when growing, the color of the colony is white and after adulthood the color of the colony turns to beige with the formation of conidia [6].

Mucor racemosus isolates with the characteristics of young white colonies and after adulthood turn brownish gray. The Mucor racemosus colony was very fast growing and covered the entire surface of the petri dish after 3-5 days. The colony is white and then brownish gray after 7 days of incubation [18], [6] and [19]

The fungus isolate Aspergillus sp has the characteristics of a white colony and after maturing blackish brown. A fungus with its colonies white light gray or yellowish and turn brown when mature and also this fungus is found in black rice lemang (Oryza sativa Siarang) [17]. which states that the fungus is isolated in various types of food, corn plants, and plant substrates, and the texture of the hairy colony of Aspergillus sp [17], [20].

The last isolate is Penicillium expansum whose colony growth is slow which when growing colony is white and after adult turns bluish green. That when a young colony was white and turned to bluish green along with the formation of conidia [9]. In addition there is a radial line on the edge of the white fungus colony. The top color is dark green with the edges of the circle white, while the bottom color is white [21].

From the picture above it can be seen that there is amylase enzyme activity in each type of fungus found in black rice lemang (Oryza sativa Siarang) which is marked by a clear area around the mushroom colony. The amylolytic index is calculated based on the quotient of the diameter of the clear region to the diameter of the colony [8]. Fungal isolates that indicate amylase-producing enzymes can be seen by measuring the diameter of the clear area around the fungal isolate and the clear area formed around the fungal isolate shows that the fungal isolate is able to hydrolyze starch [22].

The size of the diameter of the clear area formed from each isolate is different. This is due to the ability to hydrolyze starch from each isolate also varies. Based on 
the data in table 1, all 5 isolates were identified as having different amylolytic abilities. The highest amylolytic index is owned by the 5th isolate (Penicillium expansum) of 1.5. While the lowest amylolytic index was owned by the 3rd isolate (Mucor racemosus) of 0.55 . These results indicate

\section{CONCLUSION}

The results of isolation and identification of molds found in black rice lemang (Oryza sativa Siarang) obtained 5 types of molds, namely Aspegillus niger, Aspergillus ustus, Aspergillus sp., Mucor racemosus, and Penicillium expansum. Fungi found in lemang have amylolytic activity. The activity of the amylase enzyme is seen by the presence of clear areas surrounding the fungal colonies. All isolates obtained had different amylolytic index with the highest amylolytic index in the Penicillium expansum fungi isolate and the lowest index in the Mucor racemosus fungi isolate.

\section{REFERENCES}

[1] Putri, H.S., Suranto dan R. Setyaningsih. 2003. Kajian Keragaman Jenis dan Pertumbuhan Kapang dalam Acar Mentimun. Jurnal Biodiversitas ISSN, Vol 4 (1) : 18-23

[2] Rohman, A. F. 2011. Analisi Kualitas Udara Ruang (indoor) Secara Mikologis: Studi Kasus Dipemukiman Kumuh Kecamatan Semampir Surabaya. Jurnal Biologi Departemen Biologi Fakultas Sains dan Teknologi Universitas Airlangga

[3] Richana, M., Yusuf M.G., Lestari P., dan Darmadjati S.D. 1999. Perilaku Kultivasi Isolat Bakteri Termofil Penghasil $\alpha$ Amilase. J. Mikrobiol Indones

[4] Winarno, F. G. 1995. Enzim Pangan. PT. Gamedia Pustaka Umum: Jakarta

[5] Crueger, W. and A. Crueger. 1984. Biotechnology: A Textbook of Industrial Microbiology. Madison: Sinaeur Tech, Inc

[6] Samson, A.R and E.S Van-Reenen Hoeksra. 1988. Introduction Of Food Borne Fungi. Centralbureau Voor Schimme cultures Baarn. Delft.

[7] Barnett. H.L and B.B, Hunter 1998. Illustrated General Of Imperfect Fungi. Burgess Publishing Company: Minnaapolis.

[8] Mubarik, N.R., Damayanti, E. dan Listyowati, S. 2003. Isolasi dan Karakterisasi Amilase dari Kapang Alkalotoleran Asal Limbah Cair Tapioka.Biota. VIII (1), $1-8$

[9] Noverita. 2009. "Identifikasi Kapang dan Khamir Penyebab Penyakit Manusia pada Sumber Air Minum that the 5th isolate was an amylase enzyme producer with high potential criteria, followed by the 2 nd isolate, the 4 th isolate, and the first isolate with moderate potential criteria, and the 3 rd isolate criterion had low potential.

Penduduk pada Sungai Ciliwung dan Sumber Air Sekitarnya. Jurnal. ISSN 1978-9513 VIS VITALIS, Vol.2, NO.2, Universitas Nasional

[10] Karliana, I. 2009. Identifikasi Mikroba Air Laut di Ujung Grenggengan Semenanjung Muria. Jurnal Sigma Epsilon ISSN, Vol 13 (59-63).

[11] Pelczar, M. J and E.C.S. Chan 2005. Dasar-dasar Mikrobiologi. Universitas Indonesia: Jakarta.

[12] Goman, P. M. 1992. Pengantar Ilmu Pangan Nutrisi dan Mikrobiologi. Edisi Dua. Gadjah Mada University Press.

[13] Widyastuti, S. 2008. "Pengendalian Penyakit Pasca Panen, Penicillium expansum dengan Sel Khamir Rhodorotula glutinis". Makalah disajikan dalam Gelar Teknologi dan Seminar Nasional Teknik Pertanian Jurusan Teknik Pertanian Fakultas Teknologi Pertanian UGM. Yogyakarta 18-19 November 2008

[14] Waluyo, L. 2004. Mikrobiologi Umum. Universitas Muhammadiyah: Malang.

[15] Mayanti, Satria. 2009.Jamur yang Ditemukan pada Daun Cengkeh (Eugenia aromatica) di Desa Padang Karambie Kecamatan Sungai Limau. Skripsi. STKIP PGRI Sumatera Barat: Padang

[16] Alsagaff, Hood.1995. Jurnal Masalah Jamur Paru di Indonesia. Vol 15, No 1 Januari 1992.

[17] Fassatiova, O. 1986. Mould and Filamentus Fungi in Technical Microbiology. Churchill Livingstone Publ. Edinburgh, Great Britain. 217 pp

[18] Domsch,K. H.,W. Gams and H. Anderson, Traute. 1980. Campedium Of Soil Fungi. Academic Press: London

[19] Gandjar, I., R.A.Samson, K.von-den TweelVermeulen, A.Oetari, dan I.Santoso. 1999. Pengenalan Kapang Tropik Umum. Yayasan Obor Indonesia, Jakarta: xiv + 136 hlm

[20] Oktaviani, S. 2007. Isolasi, Identifikasi, Patogenitas, dan Proses Kolonisasi Cendawan Entomopatogen pada Larva Nyamuk Aedes Aegypti. (online), http://repository.ipb.ac.id, diakses 25 Juni 2013

[21] Anonymous. 2010. Kandungan dan Khasiat Beras Hitam, (Online). http://www.litbang.deptan.go.id, (diakses 10 Juli 2015).

[22] Dirnawan, H.A, Suwanto., dan Purwadaria. 2000. Eksplorasi Bakteri Termofil Penghasil Enzim Hidrolitik Ekstraseluler dan Sumber Air Panas Gunung Pancar. Hayati 7: 52-55 